NASA/CR $-96-207592$

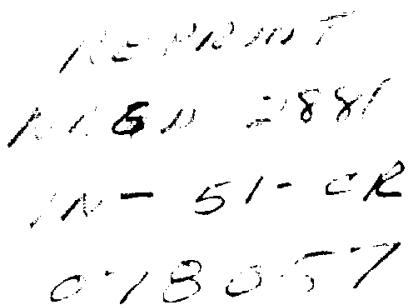

\title{
Evidence for life on Earth before 3,800 million years ago
}

\author{
S. J. Mojzsis*, G. Arrhenius*, K. D. McKeegant, \\ T. M. Harrison†, A. P. Nutman $\ddagger$ \& C. R. L. Friend§
}

- Scripps Institution of Oceanography, University of California San Diego, La Jolla, California 92093-0220, USA

†W.M. Keck Foundation Center for Isotope Geochemistry, Department of Earth and Space Sciences, University of California

Los Angeles, Los Angeles, Califomia 90095-1567, USA

¥ Research School of Earth Sciences, The Australian National University, Canberra, A.C.T. 0200. Australia

8 Department of Geology and Cartography, Oxford Brookes University, Headington, Oxford OX3 OBP, UK

It is unknown when life first appeared on Earth. The earliest known microfossils ( 3,500 Myr before present) are structurally complex, and if it is assumed that the associated organisms required a long time to develop this degree of complexity, then the existence of life much earlier than this can be argued ${ }^{1,2}$. But the known examples of crustal rocks older than $~ 3,500 \mathrm{Myr}$ have experienced intense metamorphism, which would have obliterated any fragile microfossils contained therein. It is therefore necessary to search for geochemical evidence of past biotic activity that has been preserved within minerals that are resistant to metamorphism. Here we report ion-microprobe measurements of the carbon-isotope composition of carbonaceous inclusions within grains of apatite (basic calcium phosphate) from the oldest known sediment sequences-a $\sim 3,800$-Myr-old banded iron formation from the Isua supracrustal belt, West Greenland $^{33}$, and a similar formation from the nearby Akilia island that is possibly older than $3,850 \mathrm{Myr}$ (ref. 3). The carbon in 

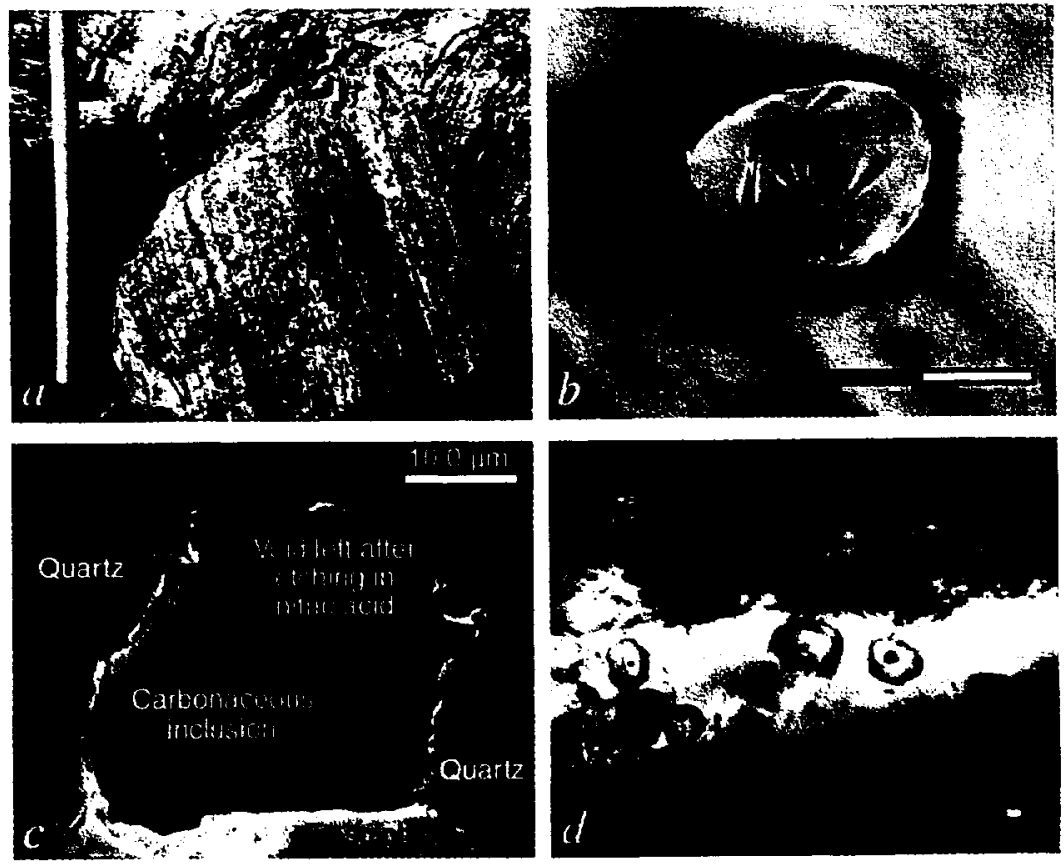

FIG. 1 a, Field exposure of the $\geqslant 3,850$-yr-old Akilia island BIF $^{3}$ (collected $150 \mathrm{~km}$ south of Isua, $63^{\prime} 55^{\prime} 40^{\prime \prime} \mathrm{N}, 51^{\prime} 41^{\prime} 30^{\prime \prime} \mathrm{W}$; photograph by A. Nutman) in southem West Greenland. Finely alternating bands of magnetite (dark) and silicates (light) are evident on the broken-off boulder which is part of a $\sim 5-\mathrm{m}$-thick section of BIF (background) on the island; the rock hammer is $\sim 40 \mathrm{~cm}$ tall. $b-d$, micrographs of anhedral, oblate apatite grains and associated carbon in early Archaean BIF. $b$. View of an apatite crystal in amphibole (grunerite), from the Akilia island BIF. The apatite was etched in $2 \% \mathrm{HNO}_{3}$ (120s at room temperature) to uncover an envelope of opaque carbonaceous matter at the grain boundary; linear features in the crystal are fission tracks from the decay of intrinsic radionuclides revealed by the etching process ( $b$ and $d$ are optical micrographs in transmitted light, oil immersion lens, plane polarized). c. Scanning electron micrograph of void left after treating apatite in $2 \% \mathrm{HNO}_{3}$ (1,800s at room temperature), revealing an acidresistant carbonaceous inclusion (centre) typical of those analysed by ion microprobe. $d$, Quartzitic microband from the Pilbara craton sediments, Western Australia, containing groupings of apatites with cores of organic matter along thin laminae of organic rich chert. Scale bars in $b$ and $d, 20 \mu \mathrm{m}$ : scale bar in $c$, $10 \mu \mathrm{m}$. the carbonaceous inclusions is isotopically light, indicative of biological activity; no known abiotic process can explain the data. Unless some unknown abiotic process exists which is able both to create such isotopically light carbon and then selectively incorporate it into apatite grains, our results provide evidence for the emergence of life on Earth by at least $3,800 \mathrm{Myr}$ before present.

Because of the unique chemical properties of phosphate and its fundamental role in a large variety of biochemical processes", the participation of phosphorus in biogeochemical cycles must be a primitive phenomenon. Authigenic phosphate minerals are a significant sedimentary component of sediments ${ }^{\text {s-k. }}$. The principal constituent of modern authigenic phosphate minerals in marine sediments is carbonate (hydroxy)fluorapatite (CHFA), $\mathrm{Ca}_{10}\left(\mathrm{PO}_{4}\right)_{6-x}\left(\mathrm{CO}_{3}\right)_{x}(\mathrm{~F}, \mathrm{OH})_{2+x}$. In the marine environment, organisms participate in concentrating organic phosphate from solution and by recycling organic phosphate species from decaying P-rich bioorganic matter ${ }^{7-11}$. Microorganisms are well known to segregate calcium from magnesium, and actively nucleate CHFA by means of specific oligopeptides ${ }^{x-10}$. Due to this common formation of authigenic CHFA, microcrystalline aggregates of apatite in modern as well as ancient sediments characteristically are intergrown with organic matter ${ }^{6-11}$. During diagenesis the aggregates recrystallize, eventually forming single apatite crystals with inclusions of carbonaceous material, which after extensive metamorphism crystallizes to graphite.

Organisms are capable of depositing apatite outside thermodynamic equilibrium in sea water with $\mathrm{pH}<8.5$ and $[\mathrm{Mg}]:[\mathrm{Ca}]>0.1$ (refs $10-12$ ), which indicates the potential value of phosphate microminerals and their associated carbonaceous inclusions as indicators of biological activity in ancient sedimentary chemical precipitates, such as chert and banded iron formations (BIFs)". The potential biogenic significance of the apatite alone can only be realized if the range of $\mathrm{Mg} / \mathrm{Ca}$ ratios and the $\mathrm{pH}$ in the source solution can be estimated independently. Even in exceptional cases, BIFs have at most minor fractions of clastic apatite derived from the weathering of igneous rocks ${ }^{13.14}$. However, such igneous apatite is free of carbon inclusions and is resistant to dissolution in natural waters; it therefore has minimal interaction with marine biogeochemical cycles and, moreover, is a relatively minor mineral constituent in most igneous rocks and their weathering detritus. But metasedimentary apatite from early Archaean BIFs, if found to contain isotopically light carbonaceous inclusions diagnostic of a bioorganic origin, might be one of the few distinguishable traces of early life in the Earth's sediments.

Carbon isotopic measurements of carbonaceous matter in sedimentary rocks have provided insights into bioorganic pathways and the evolution of early life with or without the presence of identifiable microfossils ${ }^{1,2,15-1 x}$. However, conventional methods of mass spectrometry lack the sensitivity to analyse carbon isotopes in individual apatite inclusions which are typically $\sim 10 \mu \mathrm{m}^{3}$ and contain $\sim 20 \mathrm{pg}$ carbon. The ion microprobe permits the study of isotopic variations at the scale of $10-20 \mu \mathrm{m}$ spots ${ }^{20}$. To enhince the accuracy of measurements, sputtering of each inclusion was generally continued until a large fraction of the target had been consumed. The required high sensitivity must be maintained at the relatively high mass resolving power $(M / \Delta M \approx 4.000)$ necessiry to separate interfering ${ }^{12} \mathrm{CH}^{-}$ions from ${ }^{13} \mathrm{C}^{-}$. We have tested $11 . \mathrm{C}^{\circ}$ hypothesis that carbonaceous inclusions contained in apatite trim early Archaean sediments are biogenic by using an ion microprobe to perform in situ carbon isotope measurements of such mineral microdomains in cherts and BIFs from Western Australia $(>3,250 \mathrm{Myr}$ ) and from West Greenland ( $\geqslant 3.700 \mathrm{Myr}$ ).

The Pilbara craton of northwestern Western Australia contains well preserved volcano-sedimentary sequences with ages between $\sim 3,000$ and 3,500 Myr (refs 20,21). Within the Warrawona Group, cherts from the Apex Basalt $(3.450 \pm 16 \mathrm{Myr})^{: 2}$ contain the oldest microfossils yet identified, some of which resiml $!$ : extant chemoautotrophic and photoautotrophic prokiryotic mor. photypes ${ }^{1,2}$. Whole-rock carbon isotope ratios of kerugen in the Warrawoona sediments have been interpreted to infer that photosynthesizing, or even cyanobacterium-like, orginisms were already active by $3,500 \mathrm{Myr}$ (refs $1,2,16-19$ ). The apatite intergrowths with organic matter we report here are from lower greenschist facies chert of the (>3.250 Myr) Nickol Well unit of the Roebourne belt, west Pilbara Archaean succession":2 (R. Buick, personal communication).

The Isua supracrustal belt in West Grecnland contains large volumes of early Archaean BIF and meta-cherl " " As BIFs are of sedimentary origin, these rocks are at leiw 1 . ill is their metamorphic age of 3,700 $\mathrm{Myr}^{3.21-2 \times, 15}$. Isua rock incil in lhis sludy have been metamorphosed to amphibolitc facics: detitils of the mineralogy and petrographic relationships of the Isua rocks have been given elsewhere

An early Archaean BIF encompassed within a layered amphi- 
FIG. 2 Isotope compositions of carbonaceous inclusions in individual apatite grains from early Archaean sediments measured by ion microprobe. a. West Pilbara sediments, Roebourne Belt, Western Australia (>3,250 Myr), samples courtesy of $K$. Sugitani) the data indicated by ' 1 ' are previous whole-rock measurements $^{15-17}$ of Warrawoona Group sediments for comparison; $b$, Isua supracrustal belt BIF $(>3,700 \mathrm{Myr}$; field sample no. 3381 , Isukasia, West Greenland; courtesy of E.I. Robbins and P.W.U. Appel); '2' and ' 3 ' indicate respectively previously wholerock measurements reported by Schidlowski et al. ${ }^{18}$ and Hayes $^{19}$. c, BIF from Akilia island $(\geqslant 3,850 \mathrm{Myr})$ in southern West Greenland ${ }^{3}$. d. Carbon isotope variations found in nature. Standard deviations for the ion microprobe data are indicated by the vertical lines (16). Dotted lines above and below the weighted means of the data correspond to the $2 \sigma$ confidence interval.

METHODS. Cleaned rock chips, taken several centimetres away from weathering surfaces and free from cracks, were cored to yield $25-\mathrm{mm}$ diameter rock disks of $5 \mathrm{~mm}$ thickness. These were polished with alumina powder in distilled water and drilled with an ultrasonic microcorer to produce a 3-mm-diameter hole at their centres, then sonically cleaned in successive ethanol and ultrapure water baths before being dried in air. Plugs $3 \mathrm{~mm}$ in diameter of pelletized USGS 24 graphite standard $\left(\delta^{13} C_{P D B}=-16.0 \%\right)$ were inserted into the central hole and the section was then Au-coated. Carbonaceous inclusions in the apatite were sputtered by a focused $\mathrm{Cs}$ beam in the CAMECA ims 1270 ion microprobe at UCLA, and charge compensation during negative ion extraction was maintained by using a normal-incidence electron gun. Carbon isotopic measurements were per- formed by standard ion microprobe techniques ${ }^{29.32}$ utilizing magnetic peak switching at high mass-resolving power and ion counting with an electron multiplier. The carbon isotope ratios, corrected for deadtime and instrumental mass fractionation, are reported relative to the VPOB standard using the conventional delta notation. The mass-fractionation correction procedure assumes that the degree of bias for the lighter isotope inherent in the sputtering process is the same for the carbonaceous inclusions in the apatite as for the graphite standard. Measurements on a suite of kerogen samples differing by a factor of $\sim 7$ in $\mathrm{H} / \mathrm{C}$ ratio show that the effect of such structural and compositional variations between the standard and the sample is small $\left(<2 \%\right.$ ) in agreement with earlier, less precise finding ${ }^{33}$. The inorganic carbon field is the region of carbon isotopic compositions defined as characteristic of inorganic carbonate carbon and non-bioorganic reduced carbon. bolite and ultramafic complex on Akilia island, southern West Greenland ${ }^{24}$, is cut by a deformed quartz-dioritic shect dated at $3,860 \pm 10 \mathrm{Myr}$ (ref. 3 ), providing a possible minimum age for the transected sedimentary unit. The sample used in this study (G91-26) comes from a well-preserved layer of BIF consisting of quartz $(30 \%)$, clinopyroxene $(25 \%)$, orthopyroxene $(20 \%)$, amphibole $(15 \%)$, magnetite $(5 \%)$, iron sulphides $(\sim 1 \%)$ and other minerals $(<1 \%)$ including apatite, but no observable carbonate. The unit meets the criteria of James (ref. 26) for a silicate facies to low-grade oxide facies BIF. Anhedral oblate to lozengeshaped apatite grains, occurring either individually or in groups, and resembling those found in the younger Pilbara cherts and Isua supracrustal belt samples cited above, are typically $10-15 \mu \mathrm{m}$ in diameter and $30-40 \mu \mathrm{m}$ in length (Fig. 1) and frequently contain inclusions and envelopes of graphitized carbon. Apatite grains occur in the pyroxenes, quartz, amphibole and (rarely) in magnetite, and when found in groups, are present as trains parallel to banding. In contrast, $\sim 3,860-3,870 \mathrm{Myr}$ orthogneisses from the same locality", and transecting and encompassing the supracrustals, contain igncous apatites that are devoid of graphite inclusions, are compositionally distinct, and are associated with common igneous phases such as feldspar not found in chemically precipitated sediments like BIF.

The stable isotopes of carbon are partitioned as a result of both equilibrium exchange reactions and kinclic effects, which are due to metabolic mechanisms as well as inorganic processes such as evaporation, diffusion and condensation. Kinetic isotopic fractionation between organic and inorganic carbon results in marked enrichment of the light isotope in the bionrganic component by several per cent (refs 16, 17). Hence, bionrganic materials. including carbonaccous fossils, are typically characterized ${ }^{15-18}$ by $\delta^{13} \mathrm{C}$ values of -20 to $-35 \%$ in the calse of most photoautotrophic bacteria, and can be $\mathrm{e}^{1 \mathrm{~m}-1 \mathrm{~K}}$ as light as -50 or $-60 \%$ for products of microbial communities apparently involved in the recycling of methane. In contrast, inorganic carbon is usually heavier than about $-10 \%$, with a typical range between +5 to $-5 \%$ (refs 16,17 ).

In situ ion-microprobe measurements of occluded carbon in apatite micrograins from the Akilia island BIF yield a range of $\delta^{13} \mathrm{C}$ values from $-21( \pm 2) \% 0$ to $-49( \pm 7) \%$, with a weighted mean of $-37( \pm 3) \% \circ$ (Fig. 2). Because of the micrometre size of the irregular samples embedded in apatite, the precision and

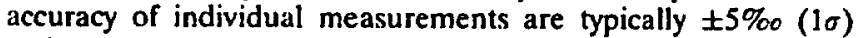
and encompass counting statistics plus an extra component for fluctuation of count-rates during analysis. Isotope results for carbonaceous inclusions in the Pilbara sediments and Isua BIF yield weighted means of $-26( \pm 3) \% c$ and $-30( \pm 3) \% c$, respectively. The results for the Pilbara sediments agree with previous whole-rock values obtained by conventional mass-spectrometric techniques for Warrawoona Group sediments ${ }^{1 /-1 x}$. All measured values from our early Archacan apatite inclusions are well resolved from what are generally considered to be inorganic carbon values.

To evaluate the presence of life in the previously oldest known sedimentary rocks, carbon isotope ratios were measured in acid insoluble carbonaceous residues (kerogens) of bulk samples from the $\geqslant 3,70()-\mathrm{Myr}$ Isua supracrustal belt BIF ${ }^{1 x}$. These measurements yielded mean $\delta^{13} \mathrm{C}$ values of -11 to $-15( \pm \sim 5 \%$ ) that have been interpreted as indicating photoautotrophic carbon fixation. However, these previous values are close to the range of inorganic carbon $\delta^{1.3} \mathrm{C}$ ratios, possibly owing to isotopic exchange with 


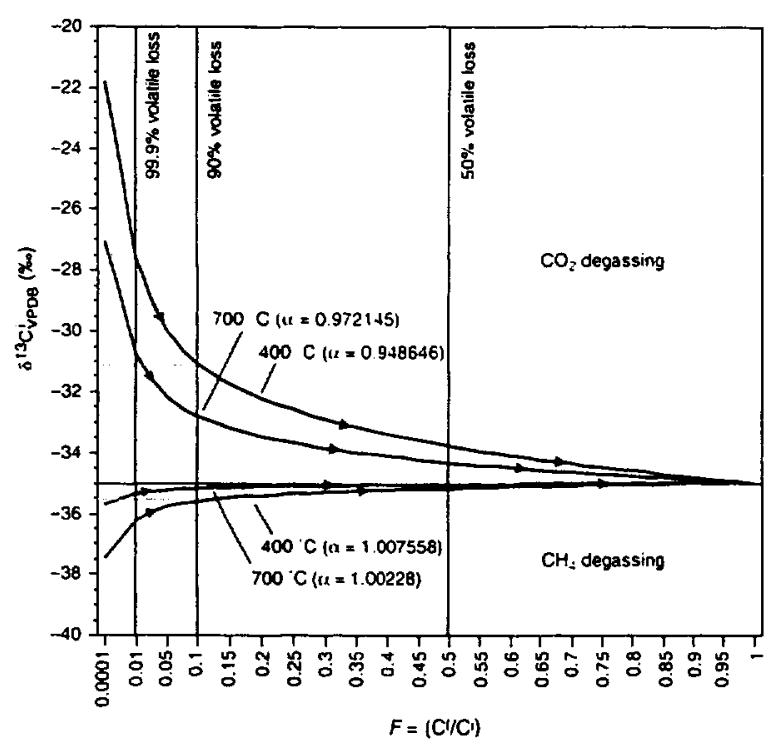

FIG. 3 Theoretical changes in the $i^{13} \mathrm{C}$ values of organic carbon by degassing of $\mathrm{CO}_{2}$ and $\mathrm{CH}_{4}$ using a Rayleigh distillation process (opensystem behaviour $)^{34} i^{13} \mathrm{C}=\left[\dot{i}^{13} \mathrm{C}^{\prime} / F^{\prime 2-1^{\prime}}\right]$ which assumes a continuously reactive (graphitic) residue and immediate loss of gas from the system with lack of continuous isotopic equilibrium between the evolved gas and the residue. The $F$-values are the mole ratios of the final residuum $\left(C^{\prime}\right.$; carbon inclusions) to the initial carbon contents of the apatites $\left(\mathrm{C}^{i}\right)$, where $i{ }^{13} \mathrm{C}^{\prime}$ is the final value of the organic carbon inclusions as measured in situ in the apatites. The $x$-values $\left(x=K_{B} ; K_{A}\right.$, which is the ratio of the equilibrium constants of isotopic exchange reactions at a given temperature) for the equilibrium isotopic fractionation factors between the evolved species $\mathrm{CH}_{2}$ (graphite-methane; $\left.\mathrm{C}-\mathrm{CH}_{4}\right), \mathrm{CO}_{2}\left(\mathrm{C}-\mathrm{CO}_{2}\right)$ versus graphite $(\mathrm{C})$ at temperatures between 400 and $700 \mathrm{C}$, the thermal metamorphic conditions experienced by the Akilia island $\mathrm{BIF}^{3:}$. are based on thermodynamical calculations $s^{33.36 .37}$. Depending on the oxygen fugacity $\left(f_{a_{2}}\right)$ of the system, metamorphism can result in the release of different proportions of $\mathrm{CO}_{2}$ and $\mathrm{CH}_{4}$. In both the $\mathrm{CO}_{2}$ and $\mathrm{CH}_{4}$ degassing, the isotopic ratio of the inclusion ('residue') would tend to increase or decrease depending on whether the expelled fluid preferentially partitions the light isotope $\left(\mathrm{CH}_{3}\right)$ or the heavy isotope $\left(\mathrm{CO}_{2}\right)$. The $\left[\mathrm{CO}_{2} / \mathrm{CH}_{3}\right]$ ratio of evolved fluids from graphite tends to increase with increasing temperature and/or decreasing pressure because of the reaction $2 \mathrm{C}+2 \mathrm{H}_{2} \mathrm{O}-\mathrm{CO}_{2}+\mathrm{CH}_{4}$. Under high $f_{0}$ conditions and at high temperatures, graphite reacting to form $\mathrm{CO}_{2}$ could yield in the thermodynamical model an isotopically lighter residue during progressive metamorphism; the graphite content in the apatite would tend in all of these cases to continually decrease. Assigning $i^{13} \mathrm{C}^{1}=-35 \%$, the figure demonstrates that even under these hypothetical and extreme conditions resulting in the loss of $\mathrm{CO}_{2}$ of $99.9 \%(F=0.001)$ of the original carbon contained in the apatites, derivation of $i^{13} \mathrm{C}$ from the inorganic isotopic field $\left(+5 \% \geqslant i^{13} \mathrm{C} \geqslant-10 \%\right.$ ) cannot be achieved, rather the range obtained is $-27.5 \% \geqslant \delta^{13} \mathrm{C} \geqslant-36.5 \%$. A theoretical $F$-value of $2.54 \times 10^{11}$ is required to go from $\delta^{13} \mathrm{C}^{\prime}=-10 \%$ (the lowermost bounds of the inorganic field in Fig. 2) to $\delta^{13} \mathrm{C}^{\prime}=-35 \%$. These calculations provide extremes in both starting compositions and open-system behaviour of the carbonaceous inclusions during metamorphism. A kinetic model would give results that only increase the ${ }^{13} \mathrm{C}^{12} \mathrm{C}$ ratio, and lead to $\delta^{13} \mathrm{C}^{\prime}$ values $\geqslant \delta^{13} \mathrm{C}^{\prime}$. The $\mathrm{x}$ axis reflects a scale change in $F$ from linear $(F=1.0-0.1)$ to nonlinear ( $F=0.1-0.0001)$ as a means of highlighting changes in $\delta^{13} C^{i}$ under extreme conditions of conversion of graphite to $\mathrm{CO}_{2}$ or $\mathrm{CH}_{4}$. carbonate carbon present in the Isua rocks during metamorphism, so they have been regarded as ambiguous'. Some carbon in igneous rocks is observed to have intermediate isotope ratios in the range of -10 to $-20 \%$, but these could reflect bioorganic contamination from assimilated sediments ${ }^{27}$. Miller-Urey sparkdischarge laboratory experiments, carried out to simulate hypothetical hydrogen-rich primitive Earth atmospheres, yield organic bulk reaction products which are ${ }^{2 x}$ isotopically heavier than $-10 \%$ and that could not have contributed to the carbon in the apatites. We can rule out reduced carbon from carbonaceous meteorites (the richest contain $\sim 3$ mass $\%$ reduced $\mathrm{C}$ ), as carbon isotope ratios for these generally cluster at $^{2 y}-11$ to $-18 \%$ and there is no reason to expect meteoritic carbon to be selectively associated with apatite in BIF. Regardless of the modes of origin for the carbon components in the various materials mentioned above, the $\delta^{1.3} \mathrm{C}$ values for the carbon inclusions in apatite are 10 $15 \%$ lighter still than the $\delta^{1.3} \mathrm{C}$ values seen in such abiogenic samples, and are characteristic of the range of carbon isotopic compositions for bioorganic matter (Fig. 2).

For strongly negative carbon isotope values in metamorphosed sediments to be convincingly interpreted as unaltered products of bioorganic fractionation, it is necessary to analyse the magnitude and sign of such effects that could have perturbed an original distribution. Empirical studies have shown that the loss process of $\mathrm{CO}_{2}$ from the oxidation of organic matter is kinetically controlled, and the evolved $\mathrm{CO}_{2}$ is isotopically lighter than the source organic carbon. Hence, loss of volatiles from thermally degrading organic matter leads to the residual organic matter being isotopically enriched in ${ }^{13} \mathrm{C}$. However, to investigate theoretical scenarios where progressive thermal metamorphism in principle could lead to enrichment of residual carbon in ' $\mathrm{C}$, we evaluated possible changes in the $\delta^{13} \mathrm{C}$ value of organic matter included in apatite under both thermodynamically open-system (Rayleigh) and closed-system (single-step) behaviours. Depending on the oxygen fugacity of the system, metamorphism can result in the release from carbonaceous matter of different proportions of $\mathrm{CO}_{2}$ and $\mathrm{CH}_{4}$ fluids, but a loss of methane which partitions the light isotope can never produce isotopic compositions lighter than the starting materials. On the other hand, the escape (during dia- genesis and metamorphism) of isotopically heavy $\mathrm{CO}_{2}$ evolved from the organic matter trapped within the apatites could, in such a theoretical model, drive the residue to lighter isotopic values. The most extreme isotopic shifts would result from a Rayleigh distillation process, which assumes a continuously reactive (graphitic) residue and immediate removal of $\mathrm{CO}_{2}$ from the system. The progressive change in ${ }^{13} \mathrm{C} /{ }^{12} \mathrm{C}$ of the graphite residue by such a Rayleigh-type process is shown in Fig. 3 as a function of the fraction of carbonaceous matter consumed in degassing to either $\mathrm{CO}_{2}$ or $\mathrm{CH}_{4}$ in the apatite. This figure shows that, for any degree of degassing and without consuming all of the carbon inclusion in the process, it is not possible to generate a final value $\left(C^{\prime}\right)$ of $\delta^{13} C^{\prime}=-35 \%$ o from an inorganic initial material $\left(C^{i}\right)$ with $\delta^{13} \mathrm{C}^{\mathrm{i}}>-10 \%$. In fact the thermodynamically determined Rayleigh evolution lines do not intersect the inorganic carbon field except toward the limit of $F=1 / \propto$, where $F$ is the mole fraction of remaining carbon. We assert that neither by kinetic nor by thermodynamic arguments, can loss of volatiles by thermal degradation of organic matter modify isotopically heavy abiotic reduced carbon to make is resemble biogenic organic carbon.

In the CHFA mineral structure, carbonate primarily substitutes for $\left[\mathrm{PO}_{4}^{3-}\right]$, and less frequently for $\left[\mathrm{OH}^{-}\right]$. Thermally induced decarbonation of CHFA occurs between 400 and $800^{\circ} \mathrm{C}$ via the decarboxylation of structural $\mathrm{CO}_{3}^{2-}$, and possibly of $\left[\mathrm{CO}_{3}^{--}, \mathrm{OH}^{-}\right]$ and $\left[\mathrm{CO}_{3}^{2-}, \mathrm{F}^{-}\right]$ion pairs ${ }^{21}$ leading to the formation of stable fluorapatite. However, there is no known mechanism that can reduce structural $\mathrm{CO}_{3}^{2-}$ in $\mathrm{CHFA}$, or its decarbonation product $\mathrm{CO}_{2}$, at low partial pressure of hydrogen, to produce carbonaceous inclusions in apatite. Any such hypothetical carbon formed by reduction of carbonate or the evolved $\mathrm{CO}$, would remain within the inorganic field of carbon isotope ratios anyway. Moreover, a simple mass-balance calculation shows that even $100 \%$ efficiency of such an assumed carbonate-reduction process could not supply the observed volume of carbonaceous inclusion contained in each of the apatites. The association of apatite with carbon is observed in the Pilbara sediments as well as in other younger, unaltered modern sediments, and in laboratory cultures of microorganisms; these features cannot be explained by metamorphism. We therefore conclude that metamorphic effect 
are not responsible for the association of isotopically light carbonaceous inclusions in metasedimentary apatite.

Together with the intergrowth of carbonaceous matter with apatite in BIF from Akilia island, we conclude that the isotopic results reported here give strong evidence for life on Earth by 3,850 Myr. Although this finding pushes back the horizon for the emergence of life by $300-400$ million years, it is not entirely unexpected ${ }^{1}$, given also the apparently evolved nature of lifeforms

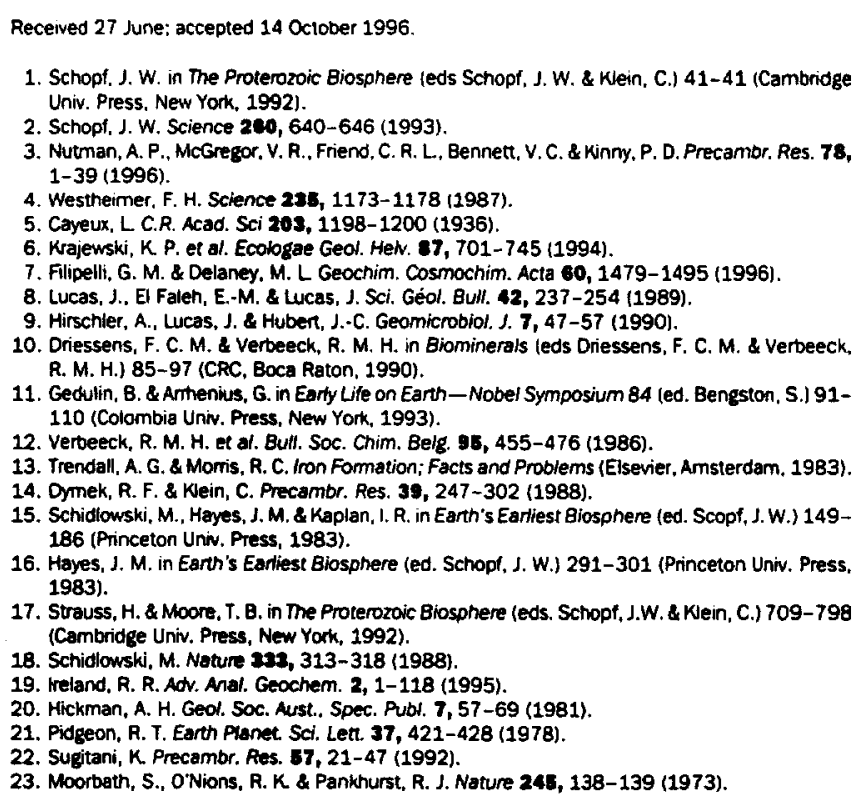

at $\sim 3,500 \mathrm{Myr}$. However, the late heavy bombardment' $(>3,800 \mathrm{Myr})$, documented in the lunar record, has been speculated to place an upper limit on the age of a continuous terrestrial biosphere $^{31}$. The evidence for life presented here overlaps this critical time period and shows that if the accretion models are realistic. such a bombardment did not lead either to the extinction of life or the perturbation of the finely laminated $>3.850-\mathrm{Myr}$ BIF preserved on Akilia island.

24. Nutman. A. P. et al. Precambr. Res. 25, 365-396 (1984).

25. Nutman. A. P. \& Collersan. K D. Geology 19, 791-794 (1991)

26. James. H. L. Econ. Geol, 49, 235-293 (1954).

27. DesMarais, D. S. \& Moore. J. G. Eanh Planet. Sci. Lett. 69, 43-57 (1984I.

28. Chang. S., Des.Marais, D. Mack, R. Miller, S. L. \& Streatheam. G. in Earth's Eartiest Biosphere (ed. Schopt. J. W.) 53-92 (Princeton Univ. Press, 1983).

29. Kerridge, J. F. Geochim. Cosmachim. Acta 49, 1707-1714 (1985).

30. Elliot, J. C. Structure and Chenistry of the Aparites and Other Calcium Orthophosphates (Elsevier. Amsterdam, 1994).

31. Chyta. C. F. Geochim. Cosmochim. Acta 57, 3351-3358 (1993).

32. McKeegan, K D.. Walker. R. M. Zinner. E. Geochim. Cosmochim. Acra 49, 1971-1987 (1985).

33. Valley, J. W. in Stabje isotopes in Hign Temperature Geologic Processes (eds Valley. J. W. . Taylor. H. P. Jr \& O'Neil, J. R.) 445-489 (Min. S $\propto$. Am., Washington DC, 1986).

34. McGregor, V. R. \& Mason, B. Am. Mineral. 62, 887-904 (1977).

35. Moorbath, S., Taylor. P. N. \& Jones, N. W. Chem. Geol. B7, 63-86 (1986).

36. Onmoto. H. \& Rye. O. O. in Geachemistry of Hydrothermal Ore Deposits (ed. Barnes, H. L.) 509 567 (Wiley, New York, 1979).

37. Chacko. Tet al. Geochim. Cosmochim. Acta 88. 2867-2882 (1991).

ACKNOWLEGEMENTS. We thank $C$. House and $J$. W. Schopt for providing well characterized kerogen samples: $C$. Coath, G. Jarzebinski and L Leshin for technical assistance with the ion kerogen samples: C. Coath, G. Jarzebinsk and $L$. Leshin for lechnical assistance with the ion microprobe; and H. D. Holland for a review of the manuscript. The UCLA ion microprobe was provided Support of the ANU, GGU, the Carisberg Foundation and Danish Natural Science Foundation (A.P.N.), Oxtord Brookes University and the Royal Sociery (C.R.L.F.) is gratefully acknowledged. This work was supported by the Earth Sclences Division of the US NSF (G.A.) and by NASA's Exobiotory Program and the NSCORT/Exabiolog (G.A., S.J.M.); turthermore, the US NSF instrument and Factities Program (T.M.H., K.D.M.).

CORRESPONDENCE should be addressed to S.M. (e-mail: smojzsis@UCsd.edu) or G.A. (e-mail: amhenius@ucso.edu). 